\title{
The Study of Worksheets Based on Creative Problem Solving for Biology Subjects.
}

\author{
Baiq Fatmawati ${ }^{1^{*}}$, Muhammad Khairul Wazni ${ }^{*}$, Novita Husnawati ${ }^{2}$ \\ ${ }^{1}$ Departement of Biology Education, Hamzanwadi University, Selong, Indonesia \\ ${ }^{2}$ SMP Islam Al Yasini NW Bungtiang, Lombok Timur, Indonesia
}

DOI: $10.29303 /$ jppipa.v7i4.831

\section{Article Info}

Received: June 7th, 2021

Revised: August 24th 2021

Accepted: October 11th 2021

\begin{abstract}
Worksheets are indispensable in the learning process because they can help students become more active and provide feedback in learning activities. Higher-order thinking skillbased worksheet is one of the teaching materials that can be used to make students become more active in the learning process because it can train problem-solving skills, critical thinking, and even creative thinking. This aimed at finding out students' ability to solve problems in biological content using creative problem-solving-based worksheets. The research design used was research and development consisting of defines, design, and development. Participants were 12 graders of XI MA Darul Fatihin NW Gerintuk. Data collection used was worksheets using creative problem-solving indicators consisting of Clarify, Ideate, Develop and Implement. Data analysis was conducted to percentage the score that gets 3,2 , and 1 . The results of the data analysis showed that 1) Ecosystem Components and interactions between components, obtained the results of ecosystem components and interactions between ecosystems, the highest percentage on clarify indicators with a gain of $50 \%$ in the score position 3; (2) Energy flow, the highest percentage on the clarify indicator with an obtained score $58.3 \%$ in the position of score 1; (3) Biogeochemical cycle, the highest percentage obtained for the students who did not answer on the ideate indicator $41.7 \%$, develop $50 \%$, and implement 58.3\%; (4) Pollution and environmental preservation the highest percentage on clarifying and ideate indicators with a gain of $50 \%$ at the position of score 3 , implement with the acquisition of $50 \%$ in the position of score 1 . This research concluded that students needed to be intensely trained in high-level thinking skills by getting used to using worksheets-based constructivist especially creative problem-solving.
\end{abstract}

Keywords: worksheets; higher-order thinking skills; creative problem solving; biology content

Citation: Fatmawati, B., Wazni, M., \& Husnawati, N. (2021). The Study of Worksheets Based on Creative Problem Solving for Biology Subjects. Jurnal Penelitian Pendidikan IPA, 7(4), 701-706. doi:https:// doi.org/10.29303/jppipa.v7i4.831

\section{Introduction}

High-level thinking needs to be applied in the process of biology learning, and especially now, it has entered the era of industrial revolution 4.0. This level of thinking skills is in accordance with the four competencies that students were integrated into the 2013 curriculum known as 4C, namely are critical, creativity, communication, and collaboratively. Arbia et al. (2020) The high school level, the process of biology learning was applicative oriented, the development of thinking skills, learning abilities, curiosity, and the development of caring attitudes and responses to the social and natural environment. Studying biology takes a high level of thinking skills in order to easily find out, at least at the stage of problem-solving, because biology learning is inseparable from the planting of skills, one of which is a skill in high-level thinking including problem-solving, decision making, critical thinking, and creative thinking.

\footnotetext{
*Email: baiq.fatmawati@hamzanwadi.ac.id
} 
Training high-level thinking students have several obstacles, one of which is integrating them into the learning process. Conradty et al. (2020) state that teachers are generally faced with pedagogical dilemmas to integrate creativity in their application in the classroom. These obstacles certainly have an impact on the lack of high-level thinking of the students because the learning methods used were less challenging and interesting. As the opinion of Sandika \& Fitrihidajati (2018) stated, the impact of less effective learning methods affects the low ability of creative thinking, scientific attitudes, motivation, and learning achievements of students.

Practicing this high level of thinking skills also needs teaching material in the form of worksheets to help students write their ideas/opinions. Otherwise, it often happens that teachers sometimes give discussion in the worksheets only measure low-level thinking ability in the level of $C_{1}$ or $C_{2}$ (term in taxonomy bloom). Kristanti et al. (2018) state that the practice questions in the worksheets received by students tend to be concepts, and no students' facilitate to construct their knowledge in developing their thinking skills. Kumalasari et al. (2017) suggest that students sometimes lack fact-capturing and lose their big ideas in expressing their opinions in biology learning. Therefore, the teaching strategy can be planned by teachers both in the learning model, media, learning resources, and teaching materials used.

One effort to create fun learning in the learning process is to use worksheets. The worksheets are a project worksheet that shows the work to be done, in which there is a summary of the material and questions that will be discussed to be completed either individually or in groups. The worksheets that will be used should be adapted to the learning methods applied. For example, if the learning method is problem-solving, the worksheets used also contain problem-solving elements or components. The same thing was also expressed by Mutia \& Prasetyo (2018) that worksheets developed according to the conditions and learning situations that students will face can achieve the desired learning objectives. In addition, student worksheets can also help students understand and be more active in constructing their knowledge of learning materials in accordance with the current 2013 curriculum guidelines (Ichsan et al. 2021; \& Khairini et al. 2021). One form of worksheets that can be used is worksheets based on creative problem-solving. Why should creative problem-solving be in developing these worksheets? According to CEF (2015), creative problem solving is used in learning (1) to create an environment in which creativity and innovation thrive. (2) to use a broad set of tools and methods to foster key behaviors conducive to creative thinking. (3) to engage personal, organizational, and social benefits of creative problemsolving. (4) to practice creative problem-solving methods in the service of personal, organizational, and social challenges. (5) to practice deliberate creativity as an integral part of the world and life. Creative problem solving is one form of teaching that is constructivist, directing students to solve problems creatively. Guilford (Phaksunchai et al., 2014; Sophonhiranraka et al., 2015) creative problem solving is one of the approaches to create a variety of solutions (requiring divergent answers) to solve the problems. Creative problem solving is a creative method of problemsolving and in the learning process using open and challenging questions, which requires imaginative and innovative different answers (Fatmawati, 2020). Based on the description, the question of this study is whether students are able to solve problems in biological materials provided using creative problem-solvingbased worksheets in high school? Astutik et al. (2020) suggested that more research is needed on workseets based on higher-order thinking skills at the primary, secondary, and upper education levels. Asma et al. (2020) also suggested designing worksheets to be more interactive and accommodate every element in the scientific process

\section{Method}

The focus of this study was to find out students' ability to solve problems in biological content using worksheets based on creative problem-solving in biology. The research design used was development research that refers to Gall et al. (2003), defining, designing, developing, and disseminating (see figure 1). For this research, dissemination has not been carried out (see yellow color).

Participants for the preliminary field testing of worksheets based on creative problem solving were 12 graders of XI MA Darul Fatihin NW Gerintuk. The data collection used was worksheets consisting of materials (1) Ecosystem Components and interactions between components, (2) Energy flow, (3) Biogeochemical cycles, and (4) Pollution and environmental preservation. To solve the problems on worksheets, creative problem-solving indicators consisting of Clarify, Ideate, Develop and Implement (CEF, 2015) were used. Data analysis was conducted by calculating students' answers and scoring 3,2, and 1 and then the percentage of scores that received 3,2 , and 1 


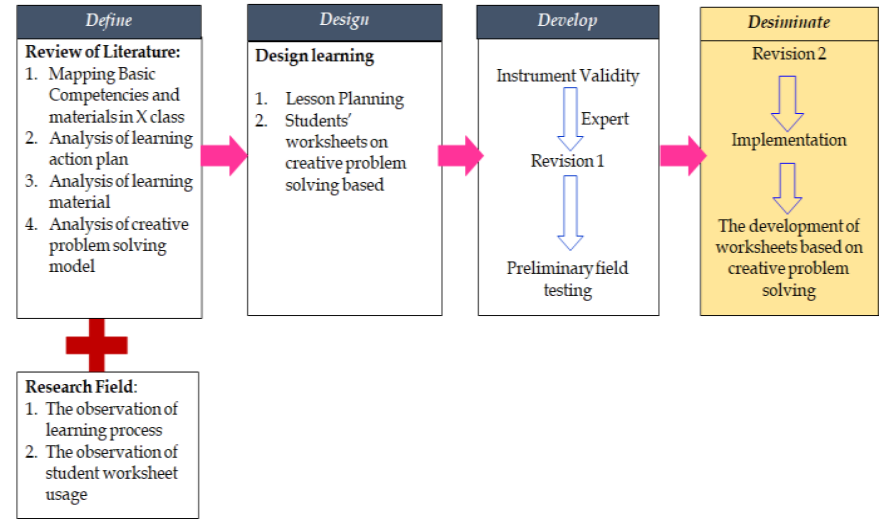

Figure 1. Research flow for developing worksheets based on creative problem-solving.

\section{Result and Discussion}

The implementation of the 2013 curriculum purposed to prepare Indonesian people to have life skills such as being productive, creative, and innovative citizens in the face of world civilization. In biology learning, the nature of learning was applicative and required higher-order thinking skills to overcome the problems found. Because the purpose of science learning, according to Zeidan \& Jayosi (2015), is to teach students to integrate skills, knowledge, and attitudes in developing scientific concepts. Therefore, teachers should be able to train their students to think high levels of course by using interesting teaching methods. Lee \& Shea (2016) stated that the teaching of science could be a planned strategy by asking scientifically oriented questions, responding to questions, formulating explanations, connecting explanations with scientific knowledge, and communicating them. Chan \& Yuen (2014) argues that many teachers believe that developing student creativity is important but do not have a pedagogical strategy. Kupers et al. (2019) also argue that providing structured and open tasks that require different solutions provides creative opportunities compared to closed tasks.

Moreover, using teaching methods that train high-level thinking is also accompanied by appropriate teaching materials. Not only do they use constructivist learning methods, but their teaching materials such as worksheets only measure low-level thinking skills. According to Khaira et al. (2020), teachers must apply various innovative strategies to make learning more meaningful, use scientific language in present concepts, and always motivate students to find information independently. One of the strategies used is to create worksheets based on higher-order thinking skills. As developed by Wahyuni et al. (2020), worksheets are developed to facilitate authentic problem-solving skills of students in the learning process. The goal of students' worksheet-based higher-order thinking skills is to explore students' high-level thinking skills, and each question is prepared by paying attention to indicators and aspects of scientific creativity skills, critical thinking, and creative thinking (Astutik et al. 2020).

Most people argued that divergent thinking used to support students' creative thinking skills is too difficult to give to students (Yayuk et al., 2020). However, it does not matter because by applying creative problem solving, students can be trained to think at high levels (creative thinking) by following creative problem-solving steps. There are four steps used in developing cps-based worksheets, namely (1) clarify; students are asked to explain/present the problems that occur based on the material presented., (2) ideate; students submit ideas/solutions related to the problems described., (3) develop; students evaluate the solutions that have been presented, and decide to take the best solution., and (4) implement; students formulate a plan based on the best solution taken is to make plans that will be done in the future. After a limited trial of students who have obtained the materials to be taught, different results are obtained in answering the worksheet. The following are presented the results of a limited trial of development worksheet based on creative problem-solving.

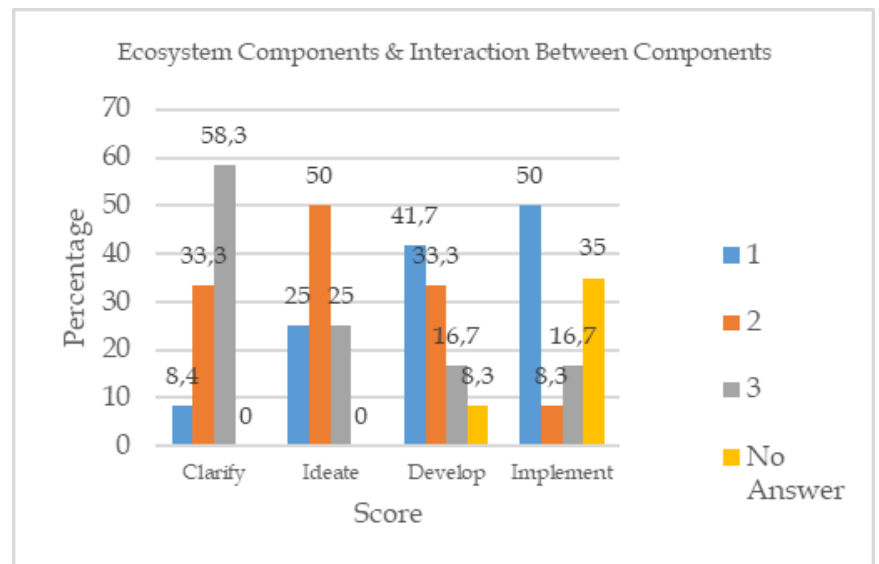

Figure 2. Percentage of students' ability to answer worksheets based on creative problem solving on ecosystem component materials and interactions between ecosystems.

Figure 2 of worksheets material about the components of ecosystem and interaction between ecosystems, students who answered in each indicator got a diverse percentage in each score. The highest was on the indicator clarify with a percentage of $50 \%$ in the position of score 3 , and students can raise the problem that occurred. But there were also students who did not answer at all, namely on the indicators develop and implement. Students seemed to be confused in making decisions from solutions that had been made and did 
not yet know how to make plans for the chosen solution.

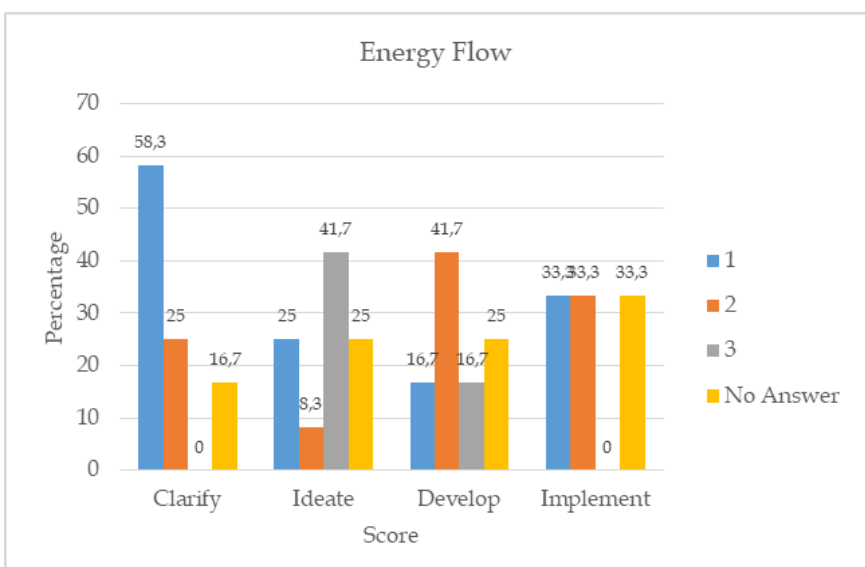

Figure 3. The percentage of students' ability to answer students' worksheets based on creative problem solving on energy flow content.

Figure 3 shows that the material about energy flow, the highest score was on the clarify indicator with a percentage of $58.3 \%$ in the position of score 1 . No students got a score of 3 , and $16.7 \%$ some students did not answer. The same result was also obtained on implementation indicators, no students scored 3, and $33.3 \%$ did not answer. From the results of the information search, this material was considered quite difficult for students.

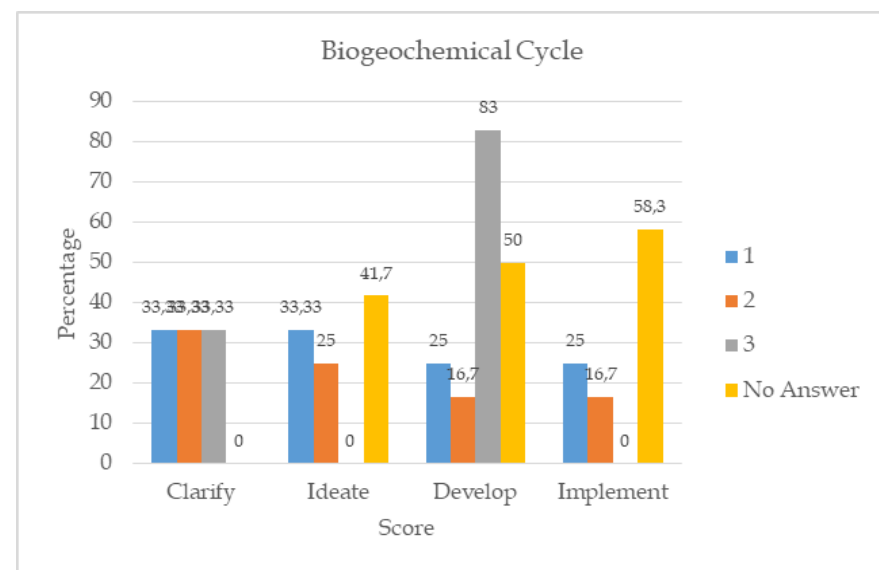

Figure 4. Percentage of students' ability to answer worksheets based on creative problem-solving in the material of biogeochemical cycle.

Figure 4 shows that the materials on biogeochemical cycle, the highest score obtained in students who did not answer on ideate indicator was $41.7 \%$, develop $50 \%$, and implementation was $58.3 \%$. In this material, biogeochemical cycle material was considered very difficult by students.

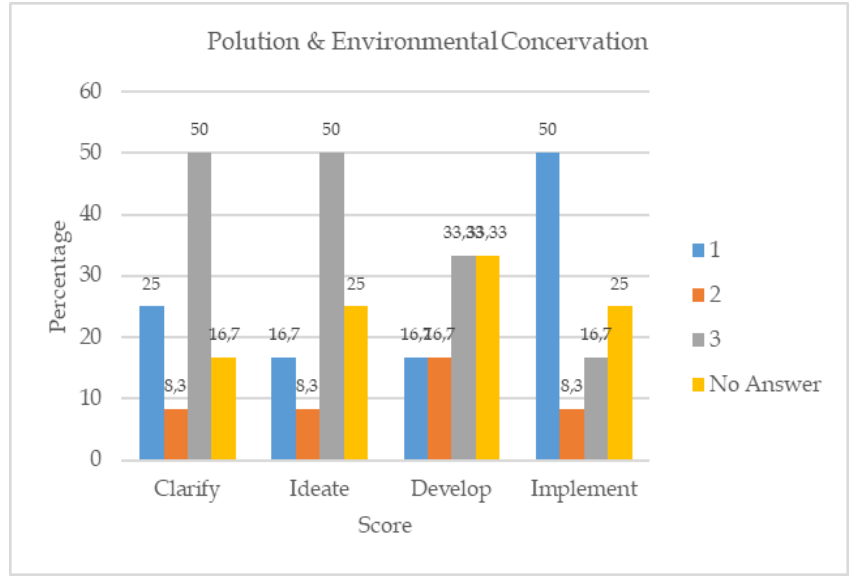

Figure 5. The percentage of students' ability to answer worksheets based on creative problem solving on pollution material and environmental preservation.

Figure 5 shows that the material about pollution and environmental preservation, every indicator of creative problem solving, namely clarify, ideate, develop and implement, there are students who did not answer questions in worksheets, students found the material very difficult to complete. The highest clarify indicator was $50 \%$ at the score position 3, ideate with a percentage of $50 \%$ on the score position 3 , in develop no one got the highest percentage, and implement with the acquisition of $50 \%$ in the position of score 1.

Viewed from the way of answering, students generally have difficulty visualizing concepts contextually in all indicators in worksheets. Kolomuc et al. (2012) have also tried to use worksheets in chemistry learning, and it turns out that students have not been able to visualize the phenomenon on the sat answering worksheets. One of the reasons is that students who have studied these materials have never received a worksheet based on a creative problem-solving model in the learning process. Worksheets used is only a common and mediocre worksheet, meaning it only measures low-level thinking ability.

In fact, training students to think at high levels was not difficult to apply as long as the teachers also mastered how to convey it because, with high-level thinking skills-based worksheets, students were able to visualize concepts contextually. Sinta et al. (2020) has also designed worksheets based on creative problem solving that are adapted by adjusting the curriculum and characteristics of the material to be taught. Patresia et al. (2020) stated that worksheets must also dynamically follow learning demands when it is important to achieve learning outcomes. With this worksheet, students can also be creative as they build new meanings, explanations, arguments, and procedures (Gomes \& McCauley, 2021). Worksheets are one of the teaching tools consisting of a series of questions and information designed to guide students 
in understanding complex ideas as they work through them systematically.

In biology, it was important to encourage creative problem-solving skills for the students in realworld life. In constructivist learning, students and teachers play a role as facilitators that guide during the learning process to give ideas in doing their work. Suwarno et al. (2019) argue that teachers are motivators and facilitators when using innovative studentcentered learning.

\section{Conclusion}

Practicing high thinking habits, especially divergent thinking at the secondary school level using teaching materials in the form of constructive worksheets, needed to be done by teachers intensely so that the problems found can be solved with imaginative and innovative solutions. Worksheets based on creative problem solving as an alternative in the learning process, in course implementation by adjusting the materials in biology subjects. The limited test results proved that students had not been able to answer questions in some indicators of creative problem-solving. Therefore, teachers needed to familiarize themselves and familiarize students to learn constructively so that students were trained in answering questions that required high levels of thinking.

\section{Acknowledgments}

Thank you to students' XI MA Darul Fatihin NW Gerintuk who have assisted in data collection, and biology and the biology teacher who has helped carry out the preliminary field testing of this students' worksheet-based creative problem-solving.

\section{References}

Arbia, S.M., Maasawet, E.T., \& Masruhim, M.A. (2020). The development of learning tools oriented industrial revolution 4.0 to improve students' creative thinking skills. International Journal of Sciences: Basic and Applied Research (IJSBAR), 51 (2), 117-131. Retrieved from: https://gssrr.org/index.php/JournalOfBasicAn dApplied/article/view/11070

Asma, R., Asrial, A., \& Maison, M. (2020). Development of Interactive Electronic Student Worksheets on Electromagnetic Induction Based on Scientific Approaches. Jurnal Penelitian Pendidikan IPA, 6(2), 136-142. doi: https://doi.org/10.29303/jppipa.v6i2.387.
Astutik, S., Mahardika, I., Indrawati, Sudarti, \& Supeno, S. (2020). HOTS student worksheet to identification of scientific creativity skill, critical thinking skill and creative thinking skill in physics learning. Journal of Physics: Conference Series, 1465, 12075.

https://doi.org/10.1088/17426596/1465/1/012075.

CEF (Creative Education Foundation). (2015) Creative problem solving resource guide. Retrievedf from: http://www.creativeeducationfoundation.org/c reative ... -process/

Chan, S., \& Yuen, M. (2014). Creativity beliefs, creative personality and creativity-fostering practices of gifted education teachers and regular class teachers in Hongkong. Thinking Skills and Create, 14, 109-118. doi. https://doi.org/10.1016/j.tsc.2014.10.003.

Conradty, C., Sotiriou, S.A, \& Bogner, F.X. (2020). How creativity in STEAM modules intervenes with self-efficacy and motivation. Education Science,10 (70), 1-15. doi: https://doi.org/10.3390/educsci10030070.

Fatmawati, B. (2020). Creative problem solving; implemented study in biology content. Journal of Physics: Conference Series, 1567, 42079. https://doi.org/10.1088/17426596/1567/4/042079.

Gall, M.D., Borg, W.R., \& Gall, J.P. (2003). Educational research: an introduction, seventh edition. New York: Longman Inc.

Gezer, S. (2015). A Case Study on Preservice Science Teachers' Laboratory Usage Self Efficacy and Scientific Process Skills. Procedia - Social and Behavioral Sciences, 174, 1158-1165. https://doi.org/10.1016/j.sbspro.2015.01.732

Gomes, D.M., \& McCauley, V. (2021). Creativity in science: A dilemma for informal and formal education. Science Education. 2021; 105. 498-520. doi: https://doi.org/10.1002/sce.21614.

Ichsan, M., Yusrizal, Y., \& Mursal, M. (2021). Development of Student Worksheets Based on React Model to Increase Student Motivation in Newton's Law Materials. Jurnal Penelitian Pendidikan IPA (JPPIPA), 7(3), 364-369. doi: https://doi.org/10.29303/jppipa.v7i3.710.

Khaira, N., Yusrizal, Gani, A., Syukri, M., Elisa \& Evendi (2020). Development of student worksheets based on comics to improve students' motivation and learning outcomes on material vibration, waves, and sound. Jurnal Penelitian Pendidikan IPA (JPPIPA). 6(2), 143-151. doi: https://doi.org/10.29303/jppipa.v6i2.424.

Khairini, K., Khaldun, I., \& Pada, A. (2021). The Effect of Student Worksheets Through the Edmodo 
Network on Concept Understanding and Independent Learning on Hydrocarbon Materials. Jurnal Penelitian Pendidikan IPA (JPPIPA), 7(3), 429-436. doi: https://doi.org/10.29303/jppipa.v7i3.701.

Kolomuç, A., Özmen, H., Metin, M., \& Açışlı, S. (2012). The Effect of Animation Enhanced Worksheets Prepared Based on 5E Model for the Grade 9 Students on Alternative Conceptions of Physical and Chemical Changes. Procedia - Social and Behavioral Sciences, 46, 1761-1765. https://doi.org/10.1016/j.sbspro.2012.05.374.

Kristanti, F., Ainy, C., Shoffa, S., Khabibah, S., \& Amin, S. M. (2018). Developing creativeproblem-solving-based student worksheets for transformation geometry course. International Journal on Teaching and Learning Mathematics, 1(1), 13-23.

doi: https://doi.org/10.18860/ijtlm.v1i1.5581.

Kumalasari, L., Yususf, H.A., \& Priyandoko, D. (2017). The application of multple intelligence approach to the learning of human circulatory system. Journal of Physics: Conf. Series, 909 (2017) 012066. doi: $\quad$ https:// doi.org/10.1088/17426596/909/1/012066.

Kupers, E., Wermser, A.L., McPherson, G., \& Geert, P. (2019). Children's creativity: a theoretical framework and systematic review. Review of Educational Research, 89 (1), 93-124. doi: https://doi.org/10.3102/0034654318815707.

Lee, C.K., \& Shea, M. (2016). An analysis of pre-service elementary teachers' understanding of inquirybased science teaching. Science Education International, 27 (2), 217-237.

Mutia, N.B., \& Prasetyo, K. (2018). The effectiveness of students' worksheet based on multiple representations to increase creative thinking skills. Journal of Education and Learning (EduLearn), 12(4), 631-637. doi: https://doi.org/10.11591/edulearn.v12i4.8487.

Patresia, I., Silitonga, M. \& Ginting, A. (2020). Developing biology students' worksheet based on STEAM to empower science process skills. Jurnal Pendidikan Biologi Indonesia, 6 (1), 147-156. doi: https://doi.org/10.2229/jpbi.v6i1.

Phaksunchai, M., Kaemkate, W., \& Wongwanich, S. (2014). Research and development of a training package for developing creative problem solving of undergraduate students. Procedia social and behavioral sciences, 116 (2014), 4824-4828. DOI: https://doi.org/10.1016/j.sbspro.2014.01.1032

Sandika, B., \& Fitrihidajati, H. (2018). Improving creative thinking skills and scientific attitude through inquiry-based learning in basic biology lecture toward students of biology education.
Jurnal Pendidikan Biologi Indonesia, 4(1), 23-28. DOI: https://doi.org/10.22219/jpbi.v4i1.5326.

Sinta, B., Hartono, Y., Indaryanti, Scristia, \& Yusup, M. (2020). Designing creative problem solving-based student worksheet for higher order thinking skills. Journal of Physics: Conf. Series, 1480 (2020) 012045. doi: https://doi.org/10.1088/17426596/1480/1/012045.

Sophonhiranraka, S., Suwannatthachoteb, P., \&Ngudgratokec, S. (2015). Factors affecting creative problem solving in the blended learning environment: a review of the literature. Procedia social and behavioral sciences, 174 (2015), 21302136.

https://doi.org/10.1016/j.sbspro.2015.02.012.

Suwarno, S., Wahidin, W., \& Nur, S. H. (2019). Projectbased learning model assisted by worksheet: It's effect on students' creativity and learning outcomes. Journal of Biological Education Indonesia, 6(1), 113-122. doi: https://doi.org/10.22219/jpbi.v6i1.10619.

Wahyuni, S., Rahayu, Y.S., \& Indana, S. (2020). Development of Problem-Based Learning Student Worksheets to Facilitate Students' Problem Solving Skills. Jurnal Penelitian Pendidikan IPA (JPPIPA), 6(2), 162-165. doi: https://doi.org/10.29303/jppipa.v6i2.427.

Yayuk, E., Purwanto, As'ari, A. R., \& Subanji. (2020). Primary school students' creative thinking skills in mathematics problem solving. European Journal of Educational Research, 9(3), 1281-1295. https://doi.org/10.12973/eu-jer.9.3.1281.

Zeidan, A.H., \& Jayosi, M.R. (2015). Science process skills and attitudes toward science among palestinian secondary school students. World Journal of Education, 5 (1), 13-24. doi: https://doi.org/10.5430/wje.v5n1p13. 